\title{
Causas y mecanismos de deterioro de los materiales pétreos del pavimento del conjunto arqueológico de Baelo Claudia, Cádiz/España
}

\section{Alteration causes and processes in the stone material from the pavement in Baelo Claudia archeological site, Cádiz/Spain}

\begin{abstract}
RESUMEN
En este trabajo se muestran los resultados de un estudio detallado sobre el estado de conservación de los materiales pétreos usados en construcciones y pavimentos de la antigua ciudad romana de Baelo Claudia (Cádiz, Sur de España). En especial, las losas del pavimento del Foro romano mostraron, en general, un alto e irreversible grado de alteración. En este estudio, se proponen medidas correctoras para una mejor preservación de las losas, amortiguando la acción de los procesos de degradación propios de condiciones subaéreas.

Dpto. de Geologí

J.C.CAÑAVERAS

Facultad de Ciencias, Dpto. de Ciencias de la Tierra y del Medio Ambiente. Univ. de Alicante

ESPAÑA

\begin{abstract}
SUMMARY
A detailed study of the alteration causes in the stone material used in buildings and pavements from the ancient roman town of Baelo Claudia (Cádiz, South Spain) was carried out to establish their degree of conservation. Slabs from the pavement of the Forum showed in general a high and irreversible degree of degradation. In order to palliate the action of processes of degradation in subaerial conditions, in this work some measures are proposed to try to preserve the slabs in better conditions.
\end{abstract}

\section{INTRODUCCIÓN}

La ciudad romana de Baelo Claudia está situada a la orilla del mar, en la bahía de Bolonia, muy próxima a la ciudad de Tarifa y al Estrecho de Gibraltar (Cádiz). Esta bahía se encuentra rodeada por las elevaciones de la Sierra de la Higuera, al N, la Sierra de la Plata, al W y la

\section{INTRODUCTION}

Ancient roman town of Baelo Claudia lies on the sea shore at Bolonia Bay, close to the town of Tarifa and the Gibraltar Strait (Cádiz). Surrounded by Sierra de la Higuera in the North, Sierra de la Plata in the West and Loma de San Bartolomé in the East,

(†): El Comité de Redacción de la revista "MATERIALES DE CONSTRUCCIÓN" se une a las muestras unánimes de pesar por el fallecimiento del Dr. Hoyos. Su prestigio y experiencia en el ámbito de la sedimentología kárstica y paleoclimatología era ampliamente reconocido por la Comunidad Cientifica nacional $e$ internacional. 
Loma de San Bartolomé, al E. Su único acceso natural es el denominado Puerto de Bolonia, al S, abierto al océano Atlántico. Baelo Claudia fue construida en el siglo II a.C. y alcanzó su máximo desarrollo durante los dos siglos siguientes, como consecuencia de su situación estratégica para el comercio entre Africa y Europa. A finales del siglo V la ciudad fue abandonada $\mathrm{y}$, posteriormente, cubierta por deslizamientos de ladera naturales. En 1917 se realizan las primeras excavaciones arqueológicas y fueron retomadas en 1966 y continuadas durante la década de los 70 (1). Tras el abandono y destrucción de la ciudad, los materiales de construcción han permanecido enterrados y sometidos a diferentes procesos de alteración durante 1.500 años, cubiertos por materiales arcillosos procedentes de las laderas próximas.

Recientemente, se han realizado algunos trabajos sobre el proceso de deterioro de la ciudad: sobre las características geotécnicas del sustrato (2); sobre paleosismicidad en su zona de ubicación (3); sobre el estado de conservación de morteros y estucos (4) y sobre el biodeterioro de los morteros $(5,6)$. Uno de los aspectos que no se han tratado en estos trabajos previos es el de la alteración de los materiales pétreos empleados en la construcción de la ciudad. El deterioro de las losas del pavimento, desde su exhumación y exposición a condiciones subaéreas hasta la actualidad, es un hecho evidente si se compara la información fotográfica obtenida durante el proceso de excavación del Foro con la obtenida durante la realización de este trabajo. El objetivo concreto del presente estudio se ha centrado en determinar las causas, etapas y mecanismos de deterioro de las losas del Foro, para definir el estado de conservación de las mismas.

\section{METODOLOGÍA}

Después de un examen detallado sobre el terreno, se tomaron un total de 32 muestras de roca y productos de alteración, correspondientes a roca fresca de las canteras de origen; losas del pavimento, con bajo grado de deterioro; losas del pavimento, con alto grado de alteración; costras superficiales de alteración; materiales detríticos de alteración de las losas; eflorescencias salinas en las losas y material detrítico del substrato infrayacente al Foro.

Mediante Difracción de Rayos-X (DRX) se determinó la composición mineralógica de las muestras, usando el cuarzo como estándar interno. Las observaciones petrográficas se basaron en el estudio de láminas delgadas en el microscopio de polarización. Una serie de muestras seleccionadas se estudiaron al Microscopio Electrónico de Barrido (MEB), equipado con EDS.
Bolonia Port in the South becomes the only natural access to the site from the Atlantic ocean. Baelo Claudia was built in the $2^{\text {nd }}$ century $B C$ and reached its top develop during the next two centuries as a result of the strategic location of the town in the trade between Africa and Europe. At the end of the $5^{\text {th }}$ century, the city was abandoned, and later natural landslides covered it. In 1917 the first archaeological steps are taken in the site, and the excavations are restarted in 1966 and continued during the 70s (1). After the abandonment and destruction of the town, the building materials have remained buried and subjected to different alteration processes for the last 1.500 years under the clay from the nearby hills.

Some research has been done on the site in past years, including: geotechnical features of the ground (2); paleoseismicity of the settlement (3); conservation degree of mortars and stuccos (4); and biological alteration of mortars $(5,6)$. One aspect not studied in these previous works is the alteration of the rocky materials used in buildings and pavements. The slabs of the latter show clear signs of weathering since the discovering and exposition to subaerial conditions up to the present time-evidence supported by the contrast between the photographic material from the excavation of the Forum and from this study. The particular objective of this work is to determine the alteration causes, stages and processes in the slabs from the pavement of the Forum in order to establish their degree of conservation.

\section{METHODS}

After a thorough examination of the area, 32 samples of rock and alteration products were selected. These belonged to fresh rock from the original quarry, low-altered pavement slabs, highaltered pavement slabs, surface alteration crusts, detrital material from weathered slabs, salt efflorescences on slabs and detrital material from the ground underlying the Forum.

$X$-Ray Diffraction (XRD) was used to determine the samples' mineralogical composition, using quartz as internal standard. The petrographic study was based on thin sections viewed under petrographic microscope, while some of the samples were observed under an EDS-equipped Scanning Electron Microscope (SEM). 
Se tomaron dos muestras de agua, procedentes de la acumulación de agua de lluvia en un afloramiento de roca arenisca de la misma formación y procedencia que las losas del Foro. En contenido en $\mathrm{Mg}^{2+}, \mathrm{Na}^{+}, \mathrm{K}^{+} \mathrm{y}$ $\mathrm{Ca}^{2+}$ de las muestras de agua se analizó en un espectrómetro de absorción atómica Perkin-Elmer, usando soluciones de referencia adecuadas de Fisher Scientific. $\mathrm{El} \mathrm{Cl}^{-}$se analizó por titración, usando nitrato de mercurio como titrante y difenilcarbasona como indicador. Los sulfatos se analizaron por turbidimetría, en un espectrómetro Perkin-Elmer 35. La alcalinidad total $\left(\mathrm{HCO}_{3}{ }^{-}-\mathrm{CO}_{3}{ }^{2-}\right)$ se determinó mediante titración con una solución estándar de ácido sulfúrico y usando fenolftaleina y naranja de metilo como indicadores. Los cálculos geoquímicos y de simulación teórica de los procesos de evaporación se llevaron a cabo empleando el programa de modelización PHRQPITZ (7).

\section{ENTORNO GEOLÓGICO Y CLIMÁTICO}

Las losas del Foro de Baelo Claudia proceden de los afloramientos de areniscas de la Unidad de Bolonia, de edad Oligoceno-Aquitaniense, muy próximos a la ciudad romana. Son areniscas finas, con estratificación paralela en niveles centimétricos, lo que facilita la extracción de losas; presentan aspecto interno masivo y color anaranjado-amarillento. En la zona de Bolonia, las areniscas se apoyan sobre materiales margosos, que actúan como impermeables $\mathrm{y}$, localmente, como nivel de base del freático. Precisamente, el pavimento del Foro, está dispuesto sobre un suelo pre-romano, constituido por arcillas y margas verde-oscuras a negras (8), producto de la alteración de dichos materiales margosos. Así, el substrato, consiste en un suelo tirsificado, indicador de la existencia de malas condiciones de drenaje (2). Estas deficiencias en el sistema de drenaje pudieron favorecer los procesos de deterioro de las losas.

En la actualidad, el suelo del Foro está notablemente deformado por ondulaciones transversales al mismo, con muchas losas descolocadas, en una disposición tipo pop-up (Figura 1) (3). Este tipo de deformación, unido a registros históricos de la destrucción de la ciudad por un importante terremoto en el siglo IV (8) y la presencia de estructuras de licuefacción en los depósitos arenosos de áreas circundantes, indican claramente los efectos sismotectónicos en la deformación del suelo del Foro.

La peculiar situación geográfica en la que se encuentra Baelo Claudia, origina unas condiciones microclimáticas especiales que van a influir directamente en el estado de conservación del conjunto arqueológico. Dada su proximidad al mar, las
Water samples were also gathered from rainfall ponds in the same sandstone formation where the forum slabs came from. Ionic contents of $\mathrm{Mg}^{2+}, \mathrm{Na}^{+}$, $\mathrm{K}^{+}$y $\mathrm{Ca}^{2+}$ were determined by a Perkin-Elmer atomic absorption spectrometer, using the adequate Fisher Scientific solution standards. Chlorine $\left(\mathrm{Cl}^{-}\right)$was calculated by titration with mercury nitrate, and by diphenylcarbasone as indicator. Sulphates were analysed by turbidimetry in a 35 Perkin-Elmer spectrometer. Total alkalinity $\left(\mathrm{HCO}_{3}^{-}-\mathrm{CO}_{3}{ }^{2-}\right)$ was also calculated by titration with a standard sulphuric acid solution and using phenolphthaleine and methyl orange as indicators. Geochemical calculations and calculations on the evaporation processes simulation were developed by the PHRQPITZ geochemical code (7).

\section{GEOLOGICAL AND CLIMATIC BACKGROUND}

The slabs from Baelo Claudia's Forum were taken from the fine-grained sandstone outcrops of the Bolonia Unit (Oligocene-Aquitanian), very close to the Roman town. This unit is characterised by a parallel, centimetric stratification, thus simplifying the extraction of the slabs. The sandstone shows a massive internal appearance and a yellowish-orange colour. At the Bolonia area it rests on impermeable marl, which acts as the base of the phreatic zone -the forum's pavement is actually over pre-Roman soil consisting of clay and of dark green to black marl (8), the alteration product of such marl-. The grounds of the forum thus represent a poorly drained soil indicating the existence of bad drainage conditions (2). These deficiencies in the drainage system could have eased the alteration processes in the slabs.

At the present time, the Forum floor is notably deformed by transversal ondulations, with many slabs out of place in a pop-up pattern (Figure 1) (3). This kind of deformation, together with historic records of the town's destruction by a major earthquake in the $4^{\text {th }}$ century (8) and the presence of liquefaction structures in the sand deposits of near areas, clearly suggest the seismo-tectonic effects in the Forum ground deformation.

The particular geographical setting of Baelo Claudia creates especial micro-climate conditions, which directly affect the degree of conservation of the archaeological site. The presence of the sea determines mild temperatures (average year temperature, 


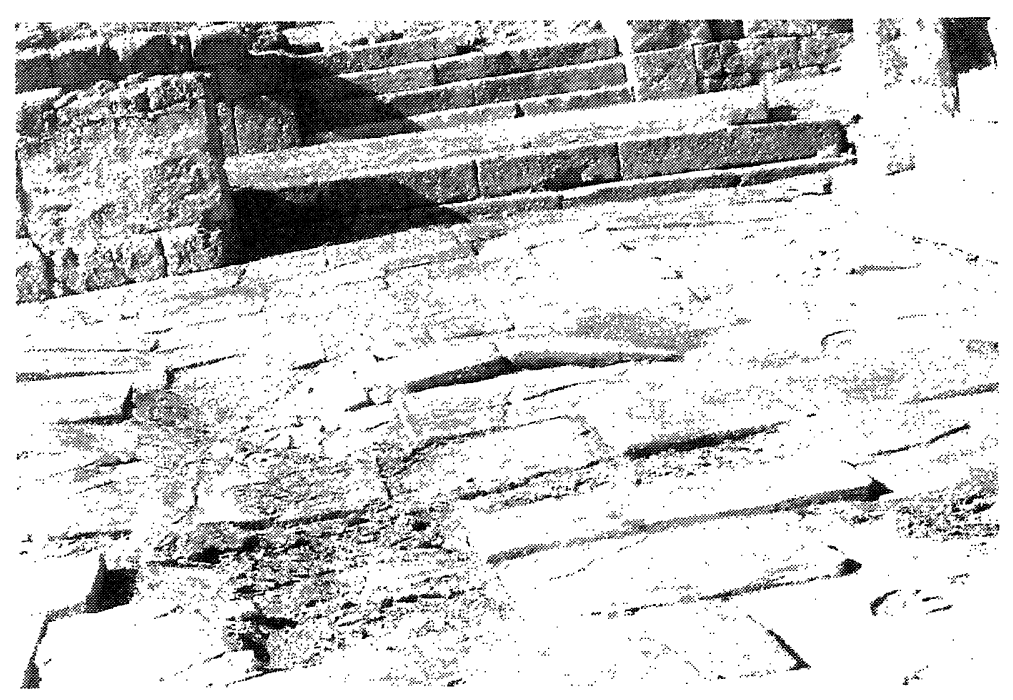

Figura 1.- Vista general del pavimento de Baelo Claudia. La deformación ondulada del suelo (pop-up) parece estar relacionada con episodios de paleo-terremotos.

Figure 1.- General view of Baelo Claudia fortum floor. Ondulated deformation (pop-up pattern) of the floor seems to be related to paleo-earthquake events.

temperaturas son suaves ( $\mathrm{T}^{\mathrm{a}}$. med. anual de $17,4^{\circ} \mathrm{C}$ ), la oscilación térmica muy baja, y no se producen heladas. El factor más destacado que caracteriza el clima de la zona es la elevada velocidad del viento, que llega a superar los $150 \mathrm{~km} / \mathrm{h}$ y que durante 60 días al año se mantiene entre 75 y $120 \mathrm{~km} / \mathrm{h}$. El efecto orográfico de barrera que ejercen las elevaciones circundantes provoca una relativa abundancia de lluvias (precipitación media anual de $760 \mathrm{~mm}$ ) y una alta y constante humedad relativa del aire, cuyo valor medio es del $76 \%$.

\section{CARACTERÍSTICAS DE COMPOSICIÓN Y PETROLÓGICAS DE LA ROCA}

En la Tabla 1 se resumen las principales características composicionales de las muestras analizadas.

\section{Roca fresca en cantera}

La roca empleada es una arenisca de grano fino, poco alterada, homométrica y de aspecto interno masivo, aunque con estratificación planar en niveles de potencia, de orden centimétrico variable. Su esqueleto está compuesto, mayoritariamente, por granos de cuarzo subredondeados, con pequeñas cantidades de feldespatos, bioclastos calcíticos, óxidos de hierro y turmalina (1\%). La matriz es arcillosa y el cemento calcítico microcristalino. En algunos casos se observan diaclasas, rellenas con cementos calcíticos, similares a las observadas en algunas losas del Foro, si bien en dichas losas, algunos de esos rellenos, aparecen afectados por procesos de disolución. $\left.17.4^{\circ} \mathrm{C}\right)$, little fluctuation and absence of frosts. The most representative of the climatic factors in the area is the strong wind, sometimes blowing faster than $150 \mathrm{~km} / \mathrm{hr}$, and between 70 and $120 \mathrm{~km} / \mathrm{hr}$ for 60 days a year. The orographic effect of the surrounding hills results in a relatively high rainfall (average year rainfall, $760 \mathrm{~mm}$ ), and a high and persistent relative air humidity (average, 76\%).

\section{COMPOSITIÓNAL AND PETROLOGICAL ROCK FEATURES}

Table 1 summarises the main compositional features of the studied samples:

\section{Fresh rock from quarry}

The sample is a fine-grained, little weathered, homometric sandstone and shows a massive internal appearance, although reveals a centimetric planar stratification in levels of different thickness. Clasts are mainly sub-rounded quartz crystals, with little amounts of feldspar, calcite bioclasts, iron oxides and turmaline (1\%). The matrix is made up of clay materials and the cement of calcite, similar to those observed in the Forum's slabs. These, however, showed dissolution processes in some of the filled-up pores. 
TABLA 1 (TABLE 1)

Principales características composicionales de las areniscas de Baelo Claudia (Main compositional features of the Baelo Claudia sandstone (\%))

\begin{tabular}{|c|c|c|c|c|c|c|c|c|c|c|}
\hline \multirow{2}{*}{\multicolumn{2}{|c|}{$\begin{array}{l}\text { MUESTRAS } \\
\text { (SAMPLES) }\end{array}$}} & \multirow[t]{2}{*}{$n$} & \multicolumn{6}{|c|}{ esqueleto (clasts) } & \multirow{2}{*}{$\begin{array}{l}\text { matriz } \\
\text { (matrix) }\end{array}$} & \multirow{2}{*}{$\begin{array}{l}\text { cemento } \\
\text { (cement) }\end{array}$} \\
\hline & & & $\mathrm{Q}$ & $\mathrm{Fel}$ & Bioc & $\mathrm{FeOx}$ & Tur & salts & & \\
\hline \multicolumn{2}{|c|}{ Roca fresca (Fresh rock) } & 4 & 60 & 5 & 5 & 2 & 1 & $\ldots$ & 5 & 22 \\
\hline \multicolumn{2}{|c|}{$\begin{array}{l}\text { Losas poco alteradas } \\
\text { (Low-altered slabs) }\end{array}$} & 5 & $55-60$ & 4 & 3 & 4 & 1 & $\ldots$ & 8 & $15-20$ \\
\hline $\begin{array}{l}\text { Losas muy } \\
\text { alteradas }\end{array}$ & $\begin{array}{l}\text { Zon. interna } \\
\text { Costra, Detritos }\end{array}$ & $\begin{array}{l}8 \\
4\end{array}$ & $\begin{array}{l}55-60 \\
50-55\end{array}$ & $\begin{array}{l}2 \\
\ldots\end{array}$ & $\begin{array}{c}4 \\
0-2\end{array}$ & $\begin{array}{c}5-10 \\
15\end{array}$ & 1 & -- & $\begin{array}{c}15 \\
20-25\end{array}$ & $\begin{array}{c}10 \\
4\end{array}$ \\
\hline $\begin{array}{l}\text { (High-altered } \\
\text { slabs }\end{array}$ & $\begin{array}{c}\text { IInner zone Crust } \\
\text { Detritum }\end{array}$ & 4 & $75-80$ & $3-5$ & 5 & 10 & $0-2$ & 5 & -- & 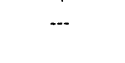 \\
\hline
\end{tabular}

$\mathrm{n}: \mathrm{n}^{\circ}$ de muestras; Q: cuarzo; Fel: feldespatos; Bioc: bioclastos; FeOx: óxidos de hierro; Tur: turmalina $\left(n: n^{\circ}\right.$ of samples; $Q$ : quartz; Fel: feldspar; Bioc: calcite bioclasts; FeOx: Iron oxides; Tur: turmalinel.

\section{. Losas poco alteradas}

Los resultados obtenidos de las observaciones petrográficas y los análisis de DRX confirman una composición muy similar a la anterior. Las principales diferencias observadas son:

- Ligero aumento de la porosidad de la roca y algunos bordes de clastos corroidos.

- Presencia de un mayor porcentaje de filosilicatos en forma de matriz arcillosa $(8 \%)$ y de óxidos de hierro $(4 \%)$.

- Leve disminución de la proporción de cemento calcítico $(15-20 \%)$.

\section{- Losas muy alteradas}

A simple vista, la mayor parte de las losas presentan un alto grado de deterioro consistente en pérdida de cohesión, disgregación de la roca y desarrollo de una costra superficial de alteración, de tono pardo oscuro y espesor milimétrico. En las losas donde dicha costra ha desaparecido, total o parcialmente, se observa una rápida arenización y formación de cubetas por acción erosiva del viento, con una pérdida de masa apreciable. Se tomaron un total de 23 muestras correspondientes a roca de la parte interna de la losa (roca alterada) (8), costra superficial (6), material detrítico suelto de alteración de la roca (4), eflorescencias salinas (5).

\section{Low-altered slabs}

Results from petrographic observations and the XRD analysis reveal a very similar composition to the above. The main differences are listed below:

- Slight increase of rock porosity. Some clasts with signs of corrosion.

- Higher percentage of phyllosilicates in the matrix (8\%) and iron oxides (4\%).

- Slight decrease of calcite cement percentage (15-20\%).

\section{. High-altered slabs}

With the naked eye most slabs look highly deteriorated, with loss of cohesion, rock disintegration, and development of a superficial milimetric, dark brown crust. The slabs with these crusts partially or totally developed also show quick disintegration and pit formation due to the wind's abrasion, with a significant mass loss. A total of 23 samples were gathered: rock from the inner side of the slabs (altered rock) (8); surface crust (6); incoherent detrital material from altered rock (4); and salt efflorescences (5). 


\section{. Roca alterada}

Las características composicionales y texturales de estas muestras presentan diferencias significativas frente a las de la "roca fresca" y losas poco alteradas. Estas diferencias son del mismo signo, pero mucho más acusadas cuando se han analizado los materiales detríticos sueltos, producto de la alteración de las losas. En conjunto, pueden resumirse en:

- Mayor tamaño de los poros, como consecuencia de la pérdida de cemento calcítico $(10 \%)$ por fenómenos de disolución. Esto provoca una fuerte disminución de la cohesión y una gran facilidad de rotura.

- Mayor abundancia de filosilicatos, como matriz arcillosa (15\%), distribuida en masas (pore-filling) o alrededor de los clastos (pore-lining). Esto coincide con una notable disminución de la proporción de feldespatos (2\%) que, en su mayor parte, aparecen muy alterados, siendo reemplazados por las arcillas de neoformación (illita, caolinita, esmectita).

- Mayor proporción de óxidos de hierro (5-10\%), sobre todo en las zonas más externas de la roca, próximas al contacto con las costras superficiales de alteración.

- Abundantes fenómenos de corrosión en los bordes de los granos de cuarzo.

\section{Costras de alteración}

Aparecen en la mayoría de las losas del Foro, cubriendo la parte superficial de la roca de una pátina parda-negra. Normalmente se encuentran cuarteadas y, en los casos en que dicha costra ha desaparecido por efecto de la erosión, la roca se encuentra fuertemente alterada y colonizada por microorganismos. El espesor de estas costras es variable, entre 2 y $8 \mathrm{~mm}$, y están constituidas por granos de cuarzo (55\%), en general de menor tamaño que en las muestras de roca; filosilicatos $(25 \%)$, con predominio de illita sobre caolinita y esmectitas en la matriz arcillosa; óxidos de hierro (14\%); calcita (4\%) neoformada y, en ocasiones, afectada por procesos de disolución y minerales salinos (2\%). Entre estos últimos se ha identificado, mediante DRX y $\mathrm{MEB}$, halita $(\mathrm{NaCl})$, thenardita $\left(\mathrm{Na}_{2} \mathrm{SO}_{4}\right)$, silvita $(\mathrm{KCl})$ y pirsonnita $\left(\mathrm{Na}_{2} \mathrm{Ca}\right.$ $\left.\left(\mathrm{CO}_{3}\right)_{2} \cdot 2 \mathrm{H}_{2} \mathrm{O}\right)$. Asimismo, en las muestras de eflorescencias salinas tomadas en la parte superficial de la roca sin costra de alteración, se han identificado cristales de halita y thenardita. En el estudio de las muestras mediante SEM se ha observado cómo los filosilicatos presentan características claras de su origen autigénico. En ocasiones se encuentran sustituyendo a feldespatos, rellenando grietas en la costra junto con abundantes microorganismos, o bien presentan disposición tipo pore-lining en torno a los granos de cuarzo.

\section{. Altered rock}

Compositional and textural properties of these samples show significant differences with those of the "fresh rock" and of the low-altered slabs. The incoherent detritus show the same differences, but these are logically stronger. The main differences are listed below:

- Larger pore size as a consequence of loss of calcite cement (10\%) due to dissolution processes. Cohesion is therefore highly reduced, and the samples break down more easily.

- Higher amounts of phyllosilicates in the matrix (15\%) either in masses (pore-filling) or around the clasts (pore-lining). This fact occurs with a reduction in the amount of feldspar (2\%), showing most of the clasts very altered and replaced by neo-formation clay (illite, kaolinite, smectite).

- Higher proportion of iron oxides (5-10\%), mainly in the areas of the rock closer to the surface, almost in touch with superficial alteration crusts.

- Abundant corrosion phenomena on the surface of the quartz grains.

\section{- Alteration crusts}

They are present on almost all the slabs in the forum, covering with a dark brown patina the rock's surface. They are usually cracked, and have sometimes been removed due to erosion. In these particular areas the rock is strongly altered and covered with colonies of microorganisms. The thickness of this crusts varies between 2 and $8 \mathrm{~mm}$, and they consist of: quartz grains (55\%), smaller in general than those in the rock samples; phyllosilicates (25\%), illite being more abundant than kaolinite and smectite in the clay matrix; iron oxides (14\%); neo-formation calcite (4\%); and saline minerals (2\%). Among the latter, XRD and SEM techniques allowed to identify halite $(\mathrm{NaCl})$, thenardite $\left(\mathrm{Na}_{2} \mathrm{SO}_{4}\right)$, sylvite $(\mathrm{KCl})$ and pirsonnite $\left(\mathrm{Na}_{2} \mathrm{Ca}\left(\mathrm{CO}_{3}\right)_{2} \cdot 2 \mathrm{H}_{2} \mathrm{O}\right)$. In the samples of salt efflorescences from the crust-free rock's surface halite and thenardite crystals have also been identified. SEM studies revealed the clear authigenic characteristics of the phyllosilicates; they are sometimes replacing feldspar, filling up cracks in the crust-together with microorganisms-, or either show a pore-lining pattern around the quartz grains. 


\section{CAUSAS Y MECANISMOS DE ALTERACIÓN DEL PAVIMENTO}

A partir de los resultados analíticos obtenidos y de las observaciones petrográficas llevadas a cabo en las muestras, los principales procesos de alteración que afectan a los materiales pétreos estudiados son:

(1) Formación de costras de alteración, enriquecidas en óxidos de hierro y arcillas de neoformación en la superficie de las losas.

(2) Cristalización de minerales salinos.

(3) Desaparición parcial del cemento carbonático.

(4) Alteración química de los feldespatos y micas.

(5) Aumento de la porosidad.

Estas transformaciones químicas han provocado un cambio en las propiedades físicas de la roca original, causando una disminución de su consistencia, un aumento de la fragilidad y dando lugar a una mayor facilidad para su disgregación.

Exceptuando la pérdida del cemento carbonático y la cristalización de minerales salinos que pueden darse bajo condiciones de exposición subaérea, el resto de los procesos han tenido que producirse durante la etapa de enterramiento del Foro. Así, se pueden distinguir dos fases diferentes de progreso de los fenómenos de deterioro de la roca, en las que han actuado distintos mecanismos de alteración: (1) Fase de enterramiento. (2) Fase de exposición subaérea. Previamente a la primera fase habría tenido lugar una etapa de exposición subaérea, que comprendería desde la instalación de las losas en el Foro hasta el abandono de la ciudad y su enterramiento. No obstante, los efectos producidos durante este período, han quedado enmascarados por los de las fases posteriores.

\section{Fase de enterramiento}

Esta fase comprende desde el enterramiento, después del abandono de la ciudad, hasta su exhumación en las excavaciones de los años 70 . Dicho enterramiento tuvo lugar en un ambiente fácilmente saturable en agua, debido a la superficialidad del nivel freático y a las malas condiciones de drenaje existentes. Esta alta disponibilidad de agua y el desarrollo de suelos incipientes facilitaron la disolución parcial del cemento carbonático y el progreso de los fenómenos de carbo-hidrólisis, como principal mecanismo de alteración. La carbo-hidrólisis comprende un conjunto de procesos sucesivos que afectan a la roca, en especial, a las que presentan mineralogía

\section{CAUSES AND PROCESSES IN THE PAVEMENT'S ALTERATION}

From analytical results and petrographic observation of the samples, the main alteration processes affecting the rocky materials are:

(1) Formation of alteration crusts, enriched in iron oxides and neo-formation clay on the slabs' surface.

(2) Crystallisation of saline minerals.

(3) Partial removal of calcite cement.

(4) Chemical alteration of feldspar and mica.

(5) Increase of porosity.

These chemical changes have led to a change in the physical properties of the original rock, reducing its consistency, increasing its frailty and facilitating its breakdown.

Except for the loss of carbonatic cement and salt mineral crystallisation - which may be produced under subaerial conditions- the rest of the phenomena observed must have been produced under subterranean conditions, after the Forum was buried by landslides. Accordingly, we may assume two different stages in the progress of the deterioration phenomena in the rock, with two different processes involved: (1) buried stage; and (2) subaerial stage. Prior to stage (1), a period of subaerial conditions -between the setting-up of the slabs and the abandonment and burying of the townmust have occurred. Nevertheless, the effects produced during later stages now mask those of this initial stage.

\section{Buried stage}

This stage corresponds to the time elapsed between the burying of the town after its abandonment and the exhumation of the ruins during the excavations that took place in the 70s. The landslides covered a terrain easily saturated with groundwater due to the proximity of the phreatic zone and the poor drainage conditions. This water availability and the development of incipient soils allowed the partial dissolution of calcite cement and the consecution of carbo-hydrolysis as the main cause for alteration processes. Carbo-hydrolysis involves a number of consecutive events affecting the rock, especially 
mayoritariamente silicatada (Figura 2A), como es el caso que nos ocupa: adsorción de agua por la roca, ataque químico (feldespatos y micas), circulación de agua, neoformación de minerales.

La expresión geoquímica de estos fenómenos de alteración y neoformación de los minerales de la arcilla identificados en nuestro estudio, es la siguiente: when rich in silicate minerals (Figure $2 \mathrm{~A}$ ), as it is the case: water adsorption, chemical attack (breakdown of feldspar and mica), water circulation, mineral. neo-formation.

The geochemical reactions for these phenomena of mineral alteration and neo-formation, are:

$$
\begin{aligned}
& 2 \mathrm{CaAlSi}_{3} \mathrm{O}_{8}+2 \mathrm{CO}_{2}+11 \mathrm{H}_{2} \mathrm{O} \quad \mathrm{Al}_{2} \mathrm{Si}_{2} \mathrm{O}_{5}(\mathrm{OH})_{4}+2 \mathrm{Ca}^{2+}+4 \mathrm{H}_{4} \mathrm{SiO}_{4}+2 \mathrm{HCO}_{3}^{-} \\
& \text {Plagioclasa (Plagioclase) } \\
& 6 \mathrm{KAlSi}_{3} \mathrm{O}_{8}+4 \mathrm{CO}_{2}+4 \mathrm{H}_{2} \mathrm{O} \quad \mathrm{K}_{2} \mathrm{Al}_{4}\left[\mathrm{Si}_{6} \mathrm{Al}_{2} \mathrm{O}_{20}\right](\mathrm{OH})_{4}+4 \mathrm{~K}^{+}+12 \mathrm{SiO}_{2}+4 \mathrm{HCO}_{3}^{-} \\
& \text {Feldespato } \mathrm{K} \text { (K-Feldspar) } \\
& \text { Illita (Illite) } \\
& 3 \mathrm{CaAl}_{2} \mathrm{Si}_{2} \mathrm{O}_{8}+6 \mathrm{H}_{2} \mathrm{O} \quad 2\left[\left(\mathrm{Al} \mathrm{Si}_{3}\right)_{10} \mathrm{Al}_{2} \mathrm{O}(\mathrm{OH})_{2}\right] \mathrm{H}+3 \mathrm{Ca}(\mathrm{OH})_{2} \\
& \text { Plagioclasa (Plagioclase) Montmorillonita (Montmorillonite) }
\end{aligned}
$$

En el caso de las minerales micáceos ferromagnesianos, como la biotita, la expresión química de su alteración es:

$$
\begin{gathered}
{\left[2 \mathrm{~K}(\mathrm{Mg}, \mathrm{Fe})_{3} \mathrm{AlSi}_{3} \mathrm{O}_{10}(\mathrm{OH})_{2}\right]+2 \mathrm{H}^{+}+10 \mathrm{H}_{2} \mathrm{O}} \\
\text { Biotita (Biotite) }
\end{gathered}
$$

Los hidróxidos de Fe emigran hacia las capas exteriores de la roca, originándose las costras de alteración de tonalidades pardas que cubren las losas. A partir de la formación de la costra, los procesos de alteración en el interior de la losa disminuyen de intensidad, debido a la relativa impermeabilidad de ésta. No obstante, tras esta fase, la roca ha perdido cohesión, quedando debilitada por la pérdida parcial del cemento carbonático y la alteración de parte de sus componentes.

\section{Fase de exposición subaérea}

El cambio de condiciones ambientales que supuso la exhumación facilita el desarrollo de nuevos mecanismos de alteración. En diferentes experimentos (9) se ha mostrado que el feldespato y mica de tamaño arena pueden ser reducidos a fragmentos de tamaño limo por cambios de temperatura, ciclos de humectación/ desecación y crecimiento de sales. Las losas del Foro han quedado expuestas a los ciclos diurnos y estacionales climáticos de cambio de temperatura y humectación/desecación, así como al efecto "spray" y acción erosiva del viento en una zona inmediata al mar.

La acción del intenso viento dominante de levante ( $\mathrm{E}$ y SE) y la inmediata situación de Baelo Claudia a la costa constituyen otro de los factores importantes en el desarrollo e intensidad de los procesos de alteración de las losas. El efecto "spray", con aporte de cloruros, la condensación de agua nocturna y la lluvia, son los mecanismos de aportes de agua y sales a la superficie de las losas. Además, el viento ejerce su acción erosiva, transportando los materiales detríticos procedentes de la arenización, favoreciendo, así, el desarrollo paulatino de las cubetas sobre la superficie de las losas.
Chemical alteration of ferromagnesian micas, such as biotite, follows the reaction below:

Kaolinite $+2 \mathrm{~K}^{+}+4 \mathrm{SiO}_{2}+5 \mathrm{H}_{2} \mathrm{O}+6(\mathrm{Mg}, \mathrm{Fe})(\mathrm{OH})_{2}$

Iron hydroxides migrate to the external rock layers, creating the dark alteration crusts over the slabs' surface. Since the formation of the crust the internal alteration processes decrease due to its relatively impermeable effect. However, after this stage, the partial loss of carbonatic cement and the alteration of part of its components make the rock less cohesive and resistant.

\section{Subaerial stage}

The change in the environmental conditions after the exhumation facilitates the way to the development of other alteration mechanisms. Different experiments (9) showed that sand-sized feldspar and mica could be reduced to silt-sized fragments by temperature changes, wet/dry cycles and salt-crystal growth. Slabs have been exposed to the daily and seasonal cycles of temperature and humidity, as well as to the "spray" effect and the wind's erosive action in a place by the sea.

The strong and predominant action of the eastern wind (S and SE), as well as the proximity of Baelo Claudia to the shore, is another main factor involved in the development and intensity of the alteration processes in the slabs. The "spray" effect, with chloride input, condensation of night water and rainfall are the principal contributors to water and salt input to the slabs. Furthermore, the wind also transports the detrital material from the rock's breakdown, enabling the formation of pits on the slabs' surface. 
La humectación/desecación provoca fenómenos de expansión/retracción de los minerales de la arcilla acumulados en la parte superficial de la costra de alteración, en especial rellenando las pequeñas grietas existentes. Este fenómeno es muy acusado en el caso de las esmectitas, con gran facilidad para la absorción y pérdida de agua. Estos continuos cambios de volumen, junto con los fenómenos de cristalización/disolución de los minerales salinos observados, provocan la rotura y fragmentación de la costra, quedando la roca alterada del interior de la losa sometida a nuevos procesos de alteración.

Los fenómenos de cristalización de sales son uno de los factores más importantes dentro de los procesos de alteración de rocas, especialmente areniscas, en ambientes costeros $(10,11)$. En las zonas costeras, el agua de lluvia contiene un amplio rango de especies iónicas, fundamentalmente cloruros y sodio, de procedencia marina (12). El efecto de barrera orográfica, ejercido por los relieves circundantes a Baelo Claudia, favorece una dispersión muy baja de las partículas de aerosol transportadas por el viento, de forma que, en esta zona, la concentración de especies disueltas en las aguas de lluvia llega a ser muy elevada.

En la Tabla 2 se presentan las principales características físico-químicas de las dos muestras de agua meteórica analizadas. Las muestras analizadas son de carácter clorurado sódico y presentan valores del pH ligeramente ácidos, como corresponde a aguas de lluvia de zonas costeras. En ambos casos, las aguas están subsaturadas frente a la calcita, de forma que su interacción inicial con la roca provocaría la disolución parcial del cemento carbonático.
Hydration/dehydration cycles cause swelling/ shrinking of the clay minerals neo-formed in the outer zone of the alteration crust, generally filling up pre-existing small cracks. This phenomenon is particularly prevalent in the case of the smectite, due to its great capacity to absorb and lose water. These systematic changes of volume, together with the crystallisation/dissolution processes observed in the salt minerals, lead to the cracking and fragmentation of the crust. New alteration processes are then able to act over the altered rock underneath.

The salt crystallisation process is one of the major factors in the alteration of rocks in coastal environments, particularly sandstone $(10,11)$. Rainwater in coastal environments contains a wide range of ionic species, mainly chlorides and sodium from the sea (12). The orographic barrier effect of the surrounding hills provokes in Baelo Claudia little dispersion of aerosol particles windtransported. This results in high concentration of the ionic particles in rainwater.

Table 2 shows the main physical-chemical features of the two water samples from rainfall. These show a sodium chloride composition and a slightly high $\mathrm{pH}$, as corresponds to rainwater from coastal environments. In both samples, water is undersaturated in calcite, which may lead to partial dissolution of calcite cement when chemically interacting with the rock.

TABLA 2 (TABLE 2)

Principales Características físico-químicas de las muestras de agua analizadas (Main physical-chemical features of the water samples)

\begin{tabular}{|c|c|c|c|c|c|c|c|c|c|c|c|}
\hline \multicolumn{2}{|c|}{$\begin{array}{l}\text { MUESTRA } \\
\text { (SAMPLE) }\end{array}$} & $\mathrm{T}\left({ }^{\circ} \mathrm{C}\right)$ & $\mathrm{pH}$ & $\mathrm{HCO}_{3}$ & $\mathrm{SO}_{4}{ }^{2 \cdot}$ & $\mathrm{Cl}^{-}$ & $\mathrm{Ca}^{2+}$ & $\mathrm{Mg}^{2+}$ & $\mathrm{Na}^{+}$ & $\mathrm{K}^{+}$ & $\mathrm{Tr}$ \\
\hline \multirow[t]{2}{*}{ AT-1 } & Ppm & \multirow[t]{2}{*}{14,3} & \multirow[t]{2}{*}{5,9} & 27,43 & 19,07 & 57,0 & 10,74 & 3,46 & 19,0 & 1,81 & nd \\
\hline & $\overline{M e q} / /$ & & & 0,45 & 0,40 & 1,61 & 0,54 & 0,28 & 0,83 & 0,05 & nd \\
\hline \multirow[t]{2}{*}{ AT-2 } & Ppm & \multirow[t]{2}{*}{15,7} & \multirow[t]{2}{*}{5,8} & 7,93 & 42,52 & 106,0 & 10,11 & 6,34 & 40,60 & 3,62 & nd \\
\hline & Meq/I & & & 0,13 & 0,88 & 2,99 & 0,50 & 0,52 & 1.77 & 0,09 & nd \\
\hline
\end{tabular}

Tr: Elementos traza ( $\left.\mathrm{Fe}, \mathrm{Mn}, \mathrm{Sr}, \mathrm{Li}, \mathrm{Cu}, \mathrm{Cd}, \mathrm{Pb}, \mathrm{Zn}, \mathrm{Ba}, \mathrm{Al}, \mathrm{Ti}, \mathrm{SiO}_{2}\right)$; T: temperatura en ${ }^{\circ} \mathrm{C}$; nd: no detectado (Tr: trace elements (Fe, $\left.\mathrm{Mn}, \mathrm{Sr}, \mathrm{Li}, \mathrm{Cu}, \mathrm{Cd}, \mathrm{Pb}, \mathrm{Zn}, \mathrm{Ba}, \mathrm{Al}, \mathrm{Ti}, \mathrm{SiO}_{2}\right) ; \mathrm{T}$ : temperature in ${ }^{\circ} \mathrm{C}$; nd: non-detectedll 
La simulación del proceso de evaporación mediante el código (PHRQPITZ) se ha realizado a partir de la muestra AT-1, debido a su menor concentración, más próxima a la original del agua de lluvia. En la Tabla 3 se muestra una síntesis de los resultados obtenidos en la simulación, a partir de la evaporación de 1 litro de solución AT-1; en ella se indican, en función del porcentaje de solución evaporado, los valores del $\mathrm{pH}$, actividad de agua $\left(\mathrm{a}_{2} \mathrm{O}\right)$ y el momento en el que se produce la precipitación individual o de varias fases salinas simultáneamente.

La secuencia obtenida explica la cristalización de las fases minerales cloruradas (halita, silvita) (Figura 2B) por un simple proceso de evaporación. Durante el proceso de evaporación, la solución va enriqueciéndose progresivamente en $\mathrm{Na}$ y $\mathrm{Cl}$ y reacciona con las fases minerales cálcicas (calcita y yeso). De esta forma, parte de la calcita se ve reemplazada por pirssonita y parte del yeso se transforma en thenardita (Figura 2C), según las reacciones:
Due to the lower concentration of some ions that make sample AT-1 closer in composition to rainwater, the PHRQPITZ modeling code was applied to it in order to study the evaporation process. Table 3 summarises the results obtained in the simulation of the evaporation of 1 l of AT-1 solution; percentage of evaporated solution, $\mathrm{pH}$ values, water activity $\left(\mathrm{a}_{2} \mathrm{O}\right)$ and precipitation relative time for individual or simultaneous precipitation of salts.

The obtained sequence explains the crystallisation of chloride mineral phases (halite, sylvite) (Figure 2B) by means of a simple evaporation process. During this process, the solution becomes progressively enriched in $\mathrm{Na}^{+}$and $\mathrm{Cl}^{-}$and reacts with the calcitic mineral phases (calcite and gypsum). In this way. part of the calcite is replaced by pirssonite, and part of the gypsum is changed into thenardite (Figure $2 C)$, the reactions for these chemical processes are:

$$
\begin{array}{ccc}
2 \mathrm{CaCO}_{3}+2 \mathrm{Na}^{+}+2 \mathrm{H}_{2} \mathrm{O} & \rightarrow \mathrm{Na}_{2} \mathrm{Ca}\left(\mathrm{CO}_{3}\right)_{2} \cdot 2 \mathrm{H}_{2} \mathrm{O}+\mathrm{Ca}^{2+} \\
\text { Calcita (Calcite) } & \text { Pirssonita (Pirssonite) } \\
2 \mathrm{CaSO}_{4} 2 \mathrm{H}_{2} \mathrm{O}+2 \mathrm{Na}^{+} \longrightarrow & \begin{array}{c}
2 \mathrm{Na}_{2} \mathrm{SO}_{4}+2 \mathrm{Ca}^{2+}+2 \mathrm{H}_{2} \mathrm{O} \\
\text { Yeso (Gypsum) }
\end{array} & \text { Thernadita (Thenardite) }
\end{array}
$$

TABLA 3 (TABLE 3)

Resultados de la simulación del proceso de evaporación de la muestra AT-1, a una temperatura de

\begin{tabular}{|c|c|c|c|c|}
\hline $\begin{array}{l}\text { EVAPORADO(\%) } \\
\text { (EVAPORATED }(\%))\end{array}$ & $\mathrm{pH}$ & a $\mathrm{H}_{2} \mathrm{O}$ & $\begin{array}{l}\text { PRECIPITADO } \\
\text { (PRECIPITATION) }\end{array}$ & $\begin{array}{l}\text { DISOLUCIÓN } \\
\text { (DISOLUTION) }\end{array}$ \\
\hline 0 & 5,90 & 0,999 & & $\begin{array}{l}\text { CALCITA } \\
\text { (CALCITE) }\end{array}$ \\
\hline 88,45 & 7,69 & 0,995 & $\begin{array}{c}\text { CALCITA + YESO } \\
\text { (CALCITE + GYPSUM) }\end{array}$ & \\
\hline 99,70 & 6,88 & 0,783 & $\begin{array}{l}\text { HALITA } \\
\text { (HALITE) }\end{array}$ & $\begin{array}{c}\text { CALCITA / YESO } \\
\text { (CALCITE / GYPSUM) }\end{array}$ \\
\hline 99,91 & 6,38 & 0,523 & $\begin{array}{l}\text { HALITA + SILVITA } \\
\text { (HALITE + SYLVITE) }\end{array}$ & \\
\hline
\end{tabular}

$17,4{ }^{\circ} \mathrm{C}$ (valor medio anual en la zona de Tarifa) y $\mathrm{PCO}_{2}=10^{-3,5} \mathrm{~atm}$.)

(Results in the modeling of the evaporation process of sample AT-1, at a temperature of $17.4^{\circ} \mathrm{C} / \mathrm{mean}$ year value in the region of Tarifal and a $\mathrm{PCO}_{2}=10^{-3.5}$ atm.) 

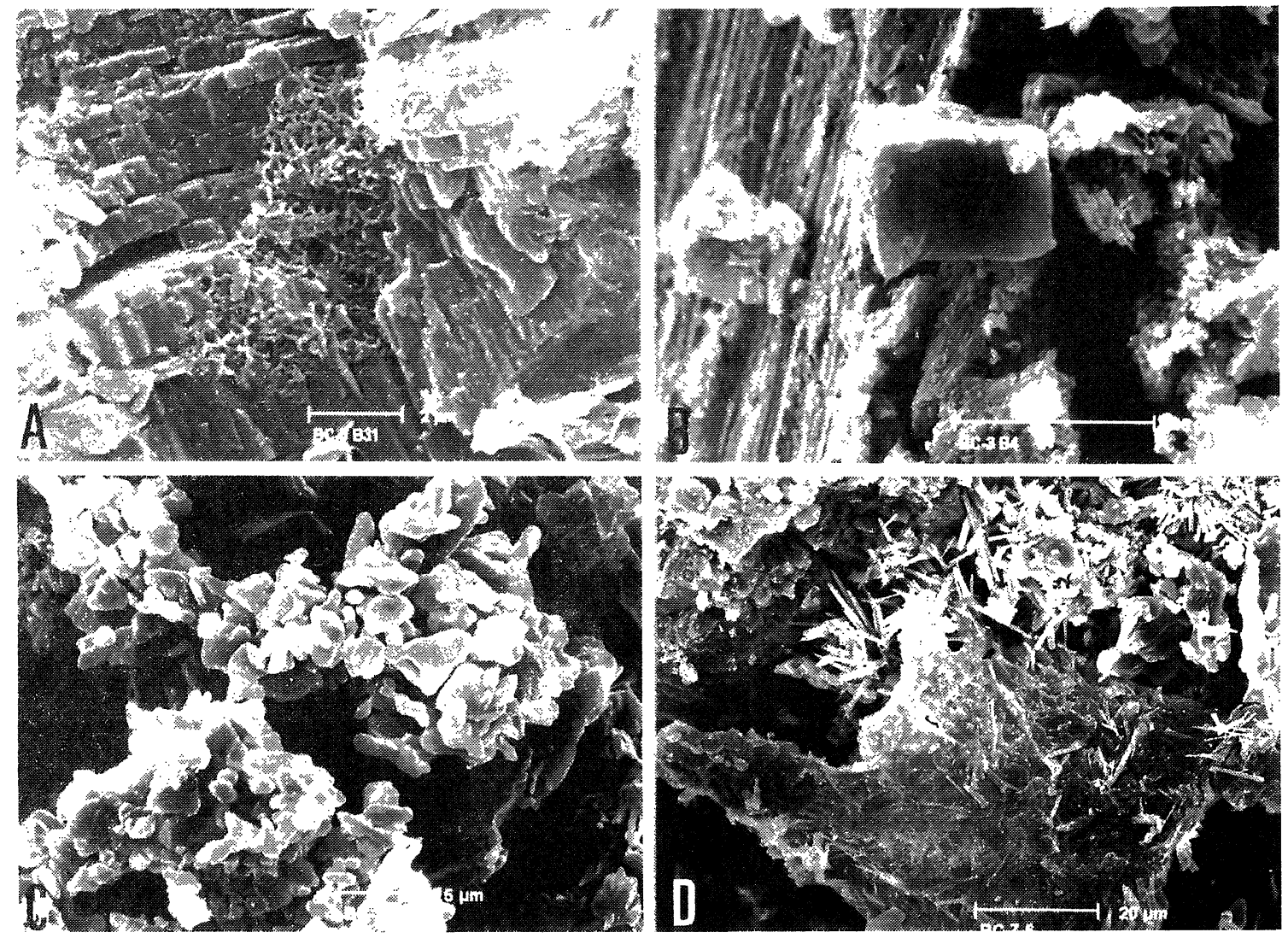

Figura 2.- Microfotografĩas de MEB. A) Alteración de albita a haloisita por procesos de carbohidrólisis. B) Detalle de un cristal de silvita. C) Agregado de cristales de carbonatos sódico-cálcicos. D) Cristales aciculares de thenardita entre masas arcillosas.

Figure 2.- SEM photomicrographs. A) Alteration of albite to halloysite by carbo-hydrolysis process. B) Detail of a sylvite crystal. C) Aggregate of Na-Ca-carbonate crystals. D) Acicular thenardite crystals between clay masses.

La precipitación de todas estas sales se produce en la superficie de la losa, donde ejercen una fuerte presión de cristalización, tanto en las micro-grietas de la costra, favoreciendo los procesos de descamación de ésta, como en los poros intragranulares de la arenisca (Figura 2D), donde favorecen la disgregación superficial de la roca en gránulos. Este proceso de arenización es muy común en las losas estudiadas y es más eficaz cuando se produce preferentemente por debajo de las costras de alteración, dado el carácter confinado del medio de cristalización y tanto mas acusado cuanto mayor es la cubeta generada en la superficie de la losa, ya que almacena mayor cantidad de agua y sales. Los valores de la presión de cristalización ejercida dependen de diversos factores (temperatura, tamaño del poro, grado de sobresaturación alcanzado por la solución, velocidad de nucleación), pero fundamentalmente, de la fase salina precipitada. Las mayores presiones de cristalización (y, por tanto, las fases salinas más efectivas como agente de alteración) corresponden a la halita, yeso y thenardita, cuya cristalización en medios confinados puede provocar presiones entre 300 y 650 atmósferas a $25{ }^{\circ} \mathrm{C}(13)$.
The precipitation of these salts occurs on the surface of the slabs, where they exert a high crystallisation pressure, both in the micro-cracks in the crust, sheeting the surface off, and in the pores between the sandstone's clasts (Figure 2D), provoking the surface's breakdown. This physical breakdown is prevalent among the studied slabs, and it is particularly efficient when it develops under the alteration crust (i.e. crystallisation occurs in a confined space), and the more intense the bigger is the pit resulting from abrasion (i.e. more water and dissolved salts accumulate). Crystallisation pressure values depend on a number of factors such as temperature, pore size, supersaturation reached by the solution and nucleation rate, but the main one is the nature of the saline phase precipitated. The highest crystallisation pressures and, therefore, the most effective salt phases as alteration agents correspond to halite, gypsum and thenardite. These salts may induce at $25^{\circ} \mathrm{C}$ pressures between 300 and 650 atmospheres (13). 
Finalmente, la acción del intenso viento dominante de levante (E y SE) transporta los materiales detríticos procedentes de la arenización de la superficie de las losas, favoreciendo el desarrollo de cubetas sobre la superficie de éstas (Figura 3).

Después de la desaparición parcial o total de la costra, se produce inicialmente el desarrollo de ligeras depresiones, bien en la zona central de la superficie de las losas o bien a favor de diaclasas, por ser estas zonas las de mayor penetración del agua y, por tanto, las primeras en degradarse. Posteriormente, conforme el proceso de arenización avanza de forma paulatina, la concavidad crece y aumenta la capacidad de embalsar agua, aumentando con ello la superficie de arenización, cuyos materiales detríticos residuales son después arrastrados por el viento, dando lugar a la formación de cubetas. Los procesos de arenización y desarrollo de cubetas son tanto más importantes cuanto más avanzado esté el proceso.

\section{CONCLUSIONES}

Las losas del Foro de Baelo Claudia presentan, en general, un grado de deterioro avanzado e irreversible, producido durante su etapa de enterramiento y aumentado con su exhumación. La vuelta a condiciones subaéreas ha dado lugar a nuevos procesos de alteración, favorecidos por esas condiciones de alteración iniciales. Si fuesen losas de roca fresca, los procesos subaéreos serían los mismos pero las consecuencias diferentes, y sobre todo, la degradación sería más lenta.
Finally, the intense E-SE wind transports all the detrital material produced by the breakdown of the slabs' surface and forms the pits over it (Figure 3).

After partial or total removal of the crust, small depressions begin to form either in the central part of the slab's surface, or where joints are present, since in these water penetrates more, and degradation of the rock occurs first. While the breakdown process gradually develops, the hollow becomes larger and deeper, increasing the alteration water capacity and the surface of action. The residual sediment is then blown off by the wind, and pits are formed. The magnitude of the breakdown processes and pit development is bigger as the process advances.

\section{CONCLUSIONS}

Slabs from Baelo Claudia's Forum show in general a high and irreversible degree of degradation produced during its buried stage and increased when exhumated. The return to subaerial conditions has risen new alteration processes favoured by the previous alteration conditions. If they were slabs from fresh rock, although the subaerial processes would have been the same, the consequences would not, and the breakdown would have occurred more slowly.

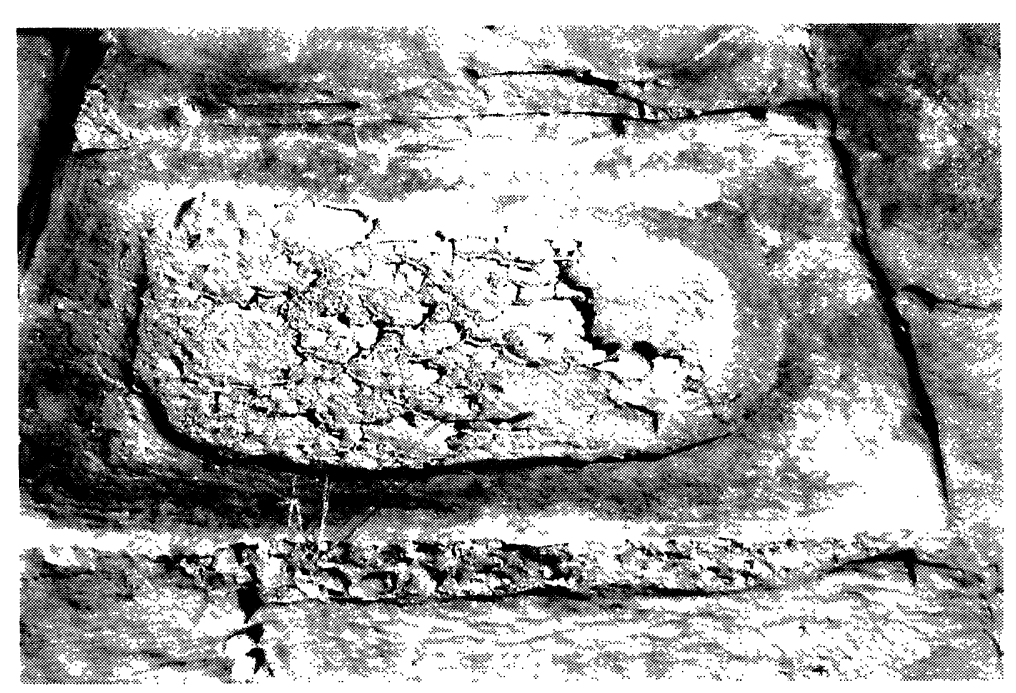

Figura 3.- Vista de una losa del Foro con desarrollo de una pequeña depresión en su superficie, producida durante la etapa subaérea de alteración.

Figure 3.- View of a Forum 's slab with development of small depressions in its surface, during the subaerial stage of alteration. 
Con objeto de paliar la acción de los procesos señalados e intentar conservar en mejores condiciones las losas por su valor arqueológico, se pueden tomar una serie de medidas que se resumen en:

(1) Proteger el ámbito del Foro de la acción del viento, sobre todo de levante, con pantallas situadas a barlovento, para el desvío y disminución de la intensidad del viento, como principal agente erosivo y de transporte de sales.

(2) Las zonas del pavimento, sobre todo donde las losas están especialmente deterioradas, podrían ser cubiertas con una capa de gravas silíceas, siempre fáciles de retirar. El objetivo sería: $1^{\circ}$ ) disminuir los efectos de la erosión hidroeólica; $2^{\circ}$ ) retener gran parte de las sales transportadas en forma de aerosol y $3^{\circ}$ ) disminuir la acción directa del Sol, con el consiguiente descenso en la evaporación rápida y en los procesos de retracción de arcillas, así como de la colonización por líquenes, algas y cianobacterias.

(3) Asimismo, se podría proceder a la instalación de una capa de arena gruesa bajo el pavimento y que facilitaría el drenaje de las aguas meteóricas, disminuyéndose los efectos de deterioro provocados por la acumulación del agua que empapa las losas.

\section{AGRADECIMIENTOS}

Los análisis mineralógicos y geoquímicos en los laboratorios del MNCN fueron realizados por R. González, M.I. Ruizy M.A. Vallejo(MNCN-CSIC).
In order to palliate the action of the processes above, and, due to the archaeological value of the site, try to preserve the slabs in better conditions, some measures, listed below, could be taken:

(1) Protect the Forum's area from the wind, mainly to the East, winward-screening it to turn and reduce the wind, as main erosion and salt transport agent.

(2) The areas of the pavement, mainly where slabs are notably altered, could be covered with siliceous gravel, easy to remove if it were the case. The expected results would be: $1^{\circ}$ ) to reduce the effects of hydro-eolic erosion; $2^{\circ)}$ to retain most salts transported in aerosol and $3^{\circ}$ ) to reduce the sun's direct sunlight, thus decreasing the quick evaporation and the shrinking processes in the clay, as well as the growth of lichen, algae and cyanobacteria colonies.

(3) Furthermore, it would be useful to improve drainage conditions of rainwater by covering the ground under the pavement with a gross sand layer. This would reduce the deteriorating effects of accumulated water soaking the slabs.

\section{AKNOWLEDGEMENTS}

Mineralogical and geochemical analyses at the MNCN Laboratory were conducted with the assistance of $R$. González, M.I. Ruiz and M.A. Vallejo (MNCN-CSIC)

\section{BIBLIOGRAFÍA}

(1) S. DARDAINE: Historique des fouilles. Publications de la Casa de Velázquez, París. Serie Archcologie Fasc IV. (1983), pp. 7-37.

(2) F. BORJA, A. MARTINEZ, A. TROYA: El proceso histórico de destrucción de la ciudad romana de Baelo Claudia (SW Cádiz). Caracterización Geotécnica y análisis de formaciones superficiales. Procesos postdeposicionales. Arqueología espacial, Vol. 1617(1993), pp. 297-308.

(3) J.L. GOY, C. ZAZO, N.A. MÖRNER, M. HOYOS, L. SOMOZA, J. LARIO, T. BARDAJI, P.G. SILVA, C. DABRIO: Pop-up like deformation of a Roman floor and liquefaction structures in SW Spain as possible paleoseismic indicators. Bull. INQUA Neotectonics Commision, Vol. 17(1994), pp. 42-44.

(4) F. PUERTAS, M.T. BLANCO-VARELA, A. PALOMO: Estucos y hormigones romanos de la ciudad de Baelo Claudia (Cádiz): Caracterización y causas de deterioro. Materiales de Construcción, Vol. 44, nº 236 (1994), pp. 15-29.

(5) C. SAIZ-JIMÉNEZ, X. ARIÑO: Colonización biológica y deterioro de morteros por organismos fotótrofos. Materiales de Construcción, Vol 45, n²40(1995), pp. 5-16.

(6) X. ARIÑO, J.J. ORTEGA-CALVO, A. GÓMEZ-BOLEA, C. SAIZ-JIMÉNEZ: Lichen colonization of the Roman pavement of Baelo Claudia (Cádiz, Spain): biodeterioration vs bioprotection. The Science of the Total Environment, Vol. 167 (1995), pp. 353-363.

(7) L.N. PLUMMER, D.L. PARKHURST, G.W. FLEMING, S.A. DUNKLE: PHRQPITZ, a computer program incorporating Pitzer's equations for calculation of gechemical reactions in brines. U.S. Gcol. Surv. Water Resources Investigation, Vol. 88 (1988), 310 p. 
(8) L. MENANTEAU, J.R. VANNEY, C. ZAZO: Baelo et son environnement (détroit de Gibraltar) Etude physique d'un site antique. Publications de la Casa de Velázquez, Paris. Serie Archeologie Fasc IV. (1983), pp. 38-221.

(9) K. PYE, C.H.B. SPERLING: Experimental investigation of silt formation by static breakage processes. Sedimentology, Vol. 30 (1983), pp. 49-62.

(10) G.E. MUSTOE: The origin of honeycomb weathering. Geological Society of American Bulletin, Vol. 93 (1982), pp. 108-115

(11) D.N. MOTTERSHEAD, K. PYE: Tafoni on coastal slopes, South Devon, U.K. Earth Surface Processes and Landforms, Vol. 19 (1994) pp. 543-563.

(12) J.I. DREVER. The geochemistry of natural waters. P. 388. Prentice Hall, New York, 1982.

(13) E. WINKLER, P.C. SINGER: Crystallization pressure of salts in stone and concrete. Bull. Geol. Soc. Am., Vol. 83, $\mathrm{n}^{\circ} 11$ (1972), pp. 3509-3513.

\section{publicación del IETCC/CSIC}

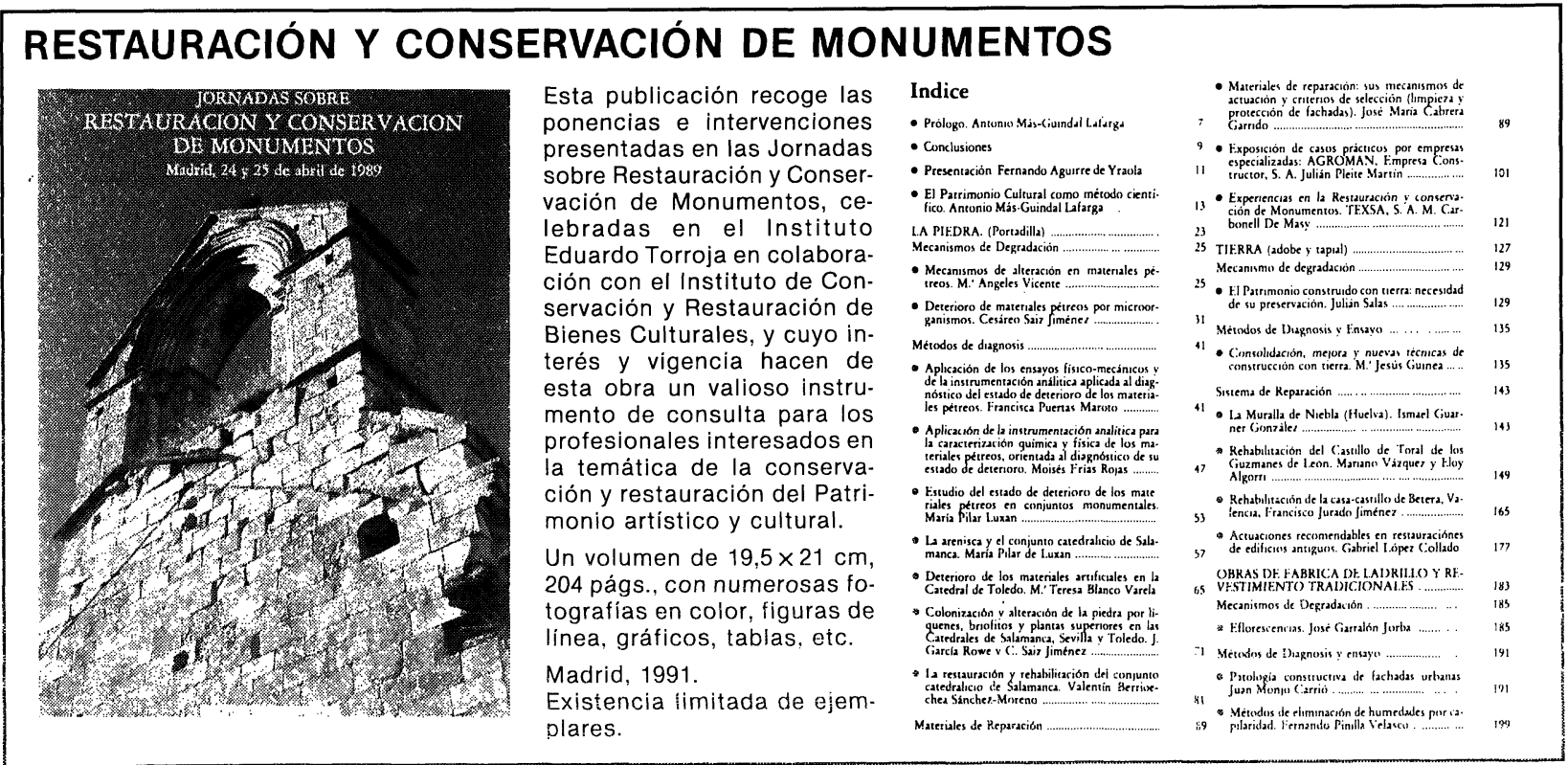

